\title{
AZ INFORMÁCIÓS ÉS KOMMUNIKÁCIÓS TECHNOLÓGIÁK (IKT) HATÁSA A VERSENYKÉPESSÉGRE
}

\author{
(Impacts of Information and Communication Technologies \\ [ICT] on Competitiveness)
}

\author{
BARSI BOGLÁRKA
}

Kulcsszavak:

versenyképesség indikátor információs-és kommunikációs technológiák Solow-paradoxon

Az új technológiák megjelenése és elterjedése felvetette egy új gazdaság megjelenésének gondolatát, mely a termelékenységben, foglalkoztatásban és gazdasági növekedésben az elmúlt években végbement rohamos változásoknak a gyüjtö szava. Az új gazdaság központi jellemzöje, hogy az információs és kommunikációs technológiák ugrásszerü fejlódése és alkalmazása innovációk egész sorát eredményezi. Mindez természetesen uaj kérdéseket vetett fel a nemzetgazdaságok, régiók, települések versenyképességének meghatározásakor, mérésekor. A szerzó az új gazdaság és a versenyképesség fogalmának magyarázata mellett a mérés körül kibontakozott vitát leginkább befolyásoló indikátorokat kíánja bemutatni. A tanulmány záró részében pedig az elmúlt években született néhány, az információs és kommunikációs technológiába való befektetés és a gazdasági vagy termelékenység-növekedés közötti kapcsolatot vizsgáló elméleti tanulmány kapcsán felmerülõ Solow-paradoxont vizsgálja.

\section{Bevezetés}

A számítástechnika, távközlés és a média konvergenciájának eredményeként ma a következő évtizedekre jellemző új társadalmi rend kibontakozásának vagyunk a tanúi: az információs társadalomnak. E folyamat ma minden országban, régióban és településen kiemelkedő kérdéssé vált, cselekvési stratégiákra ösztönözve a társadalom szereplőit. A gyors fejlődés, az állandóan változó körülmények azonban állandó monitorozásra késztetnek.

Az információs társadalom közelebb hozza egymáshoz a régiókat, országokat és városokat. A konvergens információs és kommunikációs technológiák fejlesztése és bevezetése óriási hatással van a világ minden részén található különböző típusú és méretü szervezeti egységekre.

Mindezek következtében ma már nem kerülhetô meg annak a vizsgálata, hogy mennyire felkészült egy ország és annak gazdasága az új technológiai változások nyomán kialakult új követelmények teljesítésére, mennyire képes alkalmazni a gazdaság és a társadalom (kultúra, oktatás, képzés) szegmenseiben az IKT-t, menynyire versenyképes ezen a területen is. 


\section{Az új gazdaság fogalma és legföbb jellemzöi}

Az új gazdaság fogalmát sokan sokféleképpen értelmezik. Abban azonban egyetértés van, hogy az „új gazdaság” a termelékenységben, foglalkoztatásban és a gazdasági nỏvekedésben az elmúlt években végbement rohamos változásoknak a gyủjtỏ szava. Az új gazdaság központi jellemzöje, hogy az információs és kommunikációs technológiák ugrásszerü fejlődése és alkalmazása innovációk egész sorát eredményezi. Ezek az innovációk alapvetö hatással vannak a kölcsönhatások, tranzakciók és az információfeldolgozás költségeire. Új lehetőségek és optimális megoldások jönnek létre a vállalati szervezet, piacok és innovációs folyamat hatékonyságának növelésére, melyeknek összetett és radikális hatása van a gazdaság szerkezetére és dinamikájára (Entrepreneurship in... 2001).

Az új gazdaság megjelenése számtalan tényezỏ kölcsönhatásának, összejátszásának következménye. A globalizáció fokozza a vállalatok közötti versenyt, egyrészt termelöi oldalon (minél alacsonyabb költséggel való termelés), másrészt fokozódik a nyomás a befektető́k és a tökepiacok oldaláról is. A gyáripartól a szolgáltatások felé való hosszú távú elmozdulást felgyorsította és még komplikáltabbá tette a kommunikációs és információs technológiák mindent átitató megjelenése. Az előállított termékeknek ugyanis egyre nagyobb a tudástartalma és a technikai komplexitása. Az internet és a mobil kommunikáció korábban elképzelhetetlen mértékủ információtárolást, visszakeresést, elemzést és megosztást tett lehetővé. A fejlett társadalmak egyre nagyobb összegeket fordítanak kutatásra és fejlesztésre, nagyobb hatékonysággal és gyorsabban válik a kutatási eredményből valódi alkalmazás, termék; valamint új iparágak születnek, mint a biotechnológia és géntechnika. Mindez azt eredményezte, hogy a nem megfogható eszközök - kutatás és fejlesztés, márkanév, know-how és emberi tőke - váltak a legfontosabb értékekké, a jolét forrásaivá. Az innováció és a vállalkozói képesség alakítja át ezeket a nem megfogható eszközöket termékekké és szolgáltatásokká, miközben gazdasági növekedést gerjesztenek, új munkahelyeket hoznak létre, kielégítik a társadalmi igényeket és növelik a hatékonyságot (Leadbeater-Ussher 1999).

Carayannis és Sagi szerint az új gazdaságnak 10 alapvető jellemzője van (Carayannis-Sagi 2001):

- Anyag - a biteket könnyebb alakítani, formálni, mint az atomot.

- Tér - a távolság eltünik, korlátot csak a fénysebesség jelent.

- Idő - leszúkül, összeesik.

- Ember - ötletek és kreativitás lép a tömegtermelés helyébe.

- Növekedés - a közös emberi egyưttmüködés mozdítja elö.

- Érték - fellép a „hálózati hatás”, vagyis, minél gazdagabb, bőségesebb a platform, annál értékesebb az egyed.

- Hatékonyság - az információ-közvetítők veszik át az egyéb közvetítők szerepét.

- Piac - a fogyasztók ösztönzik a keresletet és határozzák meg az árazást.

- Tranzakciók - egységenkénti, igény szerinti eladás.

- Impulzus - minden mindenuitt elérheto̊. 
Az új gazdaság alapvetô infrastruktúráját az információs és kommunikációs technikák jelentik. Az IKT rohamosan terjedt el mind a gazdaságban, mind a társadalomban, részben azért, mert korábban elképzelhetetlen módon változtatta meg az információhoz való hozzájutás, feldolgozás és tárolás módjait. Ezek a változások hozták létre aztán az úgynevezett információs technológia paradigmát (Castells 1996; 1997), mely olyan fejlődést ír le, amely egy összekapcsolt, egymástól függő, hálózati struktúrát alakít ki. Ennek a fejlödésnek a legfontosabb mozgatórugója az Internet. A világháló ugyanis lehetővé teszi, hogy szétszórtan elhelyezkedő számítógépek összekapcsolódjanak, hálózatot hozzanak létre, vagyis az egyes számítógépek egyszerre több funkciót is elláthatnak. A hálózat nyitott, tehát bárki, azonos protokollok és szabványok felhasználásával hozzáférhet.

Az új gazdaság új piaci formát is létrehoz, az elektronikus piacteret. Megjelenik az elektronikus üzletvitel (e-business) és az elektronikus kereskedelem.

Az IKT átalakítja a termékeket is. Új, teljesen digitális alapú termékek jelennek meg, melyeknek nincsen fizikai formájuk. Tudás- és információtartalmuk pedig olyan nagy, hogy legtöbbször maguk is a tudáshoz hasonló jellemzőkkel rendelkeznek: korlátlanul elérhetök és nem versenyzö termékek. Vagyis sosem fogynak el, egyszerre több fogyasztó is használhatja a termékeket. Ha egy fogyasztó letölt egy szoftvert Budapesten, és azt használja, attól az ugyanabban az idóben, Londonban a szoftvert installáló vásárló fogyasztási élvezete nem csökken. Ha a piac jól müködik, akkor komoly kihívások elé állítja ez a jelenség a társadalmat, hiszen a termékek könnyen és gyorsan áramolhatnak, cserélödhetnek, ezért megfelelő lépéseket kell tenni a tulajdonjogok biztosítása érdekében, különben a piaci szereplök elvesztik az új termékek kialakításához szükséges motivációt. Ezért szükséges szabályozni a szellemi tulajdonjogokat és a számítógépes bủnözést is (Nanclares 2001).

Mivel az új termékek fejlesztése és gyártásba állítása, valamint az értékesítés szervezése kerül elötérbe, ezért a hagyományos értelmủ termelés (termék elöállítása, összeszerelése) relatív súlya fokozatosan tovább csökken (Veress 2001).

A digitális termékek könnyen alakíthatók, módosíthatók, ezért a korábban megszokottnál sokkal jobban képesek a termékek elóállítói a fogyasztói igényeknek megfelelni. Az alkalmazkodás szinte teljesen rugalmassá válhat.

A kutatás és fejlesztés szerepe megnövekedett, a vállalatok egyre többet fordítanak $\mathrm{K}+\mathrm{F}-\mathrm{re}$.

A szereplők is átalakulnak, valamint új szereplök is megjelennek. A fogyasztó szélesebb, bővebb információval rendelkezik, mint korábban, most jutottunk talán legközelebb a tơkéletes informáltsághoz. A piacok 24 órán át, folyamatosan hozzáférhetök, jelentősen csökken tehát a piacok távolságának, vagy akár a különböző időzónáknak a szerepe. A vállalkozásoknál jelentősen csökkennek a tranzakciós költségek, a termelési tényezök árai, kisebb a raktározási szükséglet, gyorsabb a piacra jutás. 


\section{Versenyképesség és új gazdaság}

A versenyképesség fogalmát sokféleképpen értelmezhetjük, többféle szempontból vizsgálhatjuk. Beszélhetünk termékek, gazdasági ágazatok, nemzetgazdaságok versenyképességéröl hosszú és rövid távon.

Ezek közuil a legkomplexebb fogalom természetesen a nemzetek versenyképessége. Néhány szerző azonban tagadja a versenyképesség makroökonómiai értelmezhetőségét. Krugman szerint például a versenyképesség egy veszélyes rögeszme (Krugman 1994). Egy ország fő célját, a reáljövedelem és az életszínvonal nỏvekedését a termelékenység határozza meg.

Porter hasonlóképpen vélekedik (Porter 1990), amikor úgy fogalmaz, hogy nemzeti szinten egyedül a termelékenységgel, illetve a termelékenység növekedésével lehet leírni a versenyképességet. A nemzetközi kereskedelem nem zéró összegü játék és az államok nem lehetnek versenyképesek a gazdaságok valamennyi ágazatában. Egy gazdaság központi kihívása tehát, hogy hogyan lehet a gyors és fenntartható növekedéshez szükséges feltételeket megteremteni. Porter szerint habár a stabil politikai és jogi környezet és a megbízható makroökonómiai politika teremtik meg a nemzeti jólét növelésének lehetőségét, de a jólétet valójában mikroökonómiai szinten a vállalatok termék és szolgáltatás elöállítási képessége hozza létre (Porter 2002).

A másik széles körben elterjedt felfogás szerint a makrogazdaságok nemzetközi versenyképessége igenis mérhetỏ (Lengyel 2000). Az ex post versenyképesség a gazdaság realizált, múltbeli teljesítményére utal. Input oldalon az ex post versenyképesség mutatói az innovációs képesség, a költségek színvonala, a makrogazdasági stabilitás, míg output oldalon a termelékenység, a GDP növekedési üteme, a kereskedelmi mérleg, a piaci részesedés, cserearányok, valutaárfolyam stabilitása (Palánkai 2002).

$\mathrm{Az}$ ex ante versenyképesség nem a gazdasági teljesítmény valamely mutatóját vagy mutatórendszerét, hanem a vállalati versenyelőnyöket nyújtó tényezőket, a globális versenyben való sikeres helytállás háttérfeltételeit, az üzleti környezet elemeinek fontosságát hangsúlyozza (Lengyel 2000, 972).

A nemzetközi versenyképesség ebben a tág értelemben tehát egy ország képességét jelenti a hosszú távú gazdasági növekedés, valamint egy olyan gazdasági szerkezet elérésére, amely könnyen alkalmazkodik a világpiaci igények változásához (Clark-Guy 1997). A gyors alkalmazkodás elengedhetetlen feltétele az innovációk generálása, alkalmazása és terjesztése. Ebben elsődleges az információs és kommunikációs technológiák szerepe, ugyanis képessé teszik az egyes vállalatokat, hogy a versenyképességhez nélkülözhetetlen szervezeti, folyamat és termék innovációkat hajtsanak végre. Az új gazdaságban tehát a versenyképességet úgy lehet megfogalmazni, mint egy nemzet képességét az IKT adta lehetőségek legteljesebb kihasználására.

A technológiának igen nagy szerepe van a versenyképességben. Az International Institute for Management Development (IMD) és a World Economic Forum (WEF) által kỏzzétett versenyképességi indexben a technológia 50 százalékos súlyt képvi- 
sel az indexen belül. Az IKT nyilvánvalóan csak része, habár igen fontos része a technológiának.

A technológia, így az IKT is kapcsolódik mind a költség, mind az innovatív versenyképességhez, mert a technológia az emberek jólétének növekedéséhez is hozzájárulhat.

Az IKT országok, nemzetgazdaságok versenyképességére gyakorolt hatásának vizsgálata mellett, hamarosan elötérbe került mind a nemzetközi, mind a hazai szakirodalomban (Barsi-Csizmadia 2001; Barsi 2002; Nagy 2002; RechnitzerGrosz-Csizmadia 2003; Rechnitzer 2003) az új technológiák térszerkezetre, a tér egyes elemeinek versenyképességére gyakorolt hatása is. A kutatók elsősorban arra kívántak választ kapni, hogy az új technológiák vajon reprodukálják-e a korábbi gazdasági térszerkezetet, ráerösítenek-e az egyes régiók, térségek, települések közötti versenyképességi különbségekre, vagy új, a korábbitól eltérỏ térszerkezetet hoznak létre.

Alfred Marshall (Marshall 1890) már több mint egy évszázada azt írta, hogy a kommunikációs eszközök olcsóbbá válása megváltoztatja azokat a kényszerítö erőket, amelyek az egyes iparágak letelepítését befolyásolják. Azóta az információs és kommunikációs technológiák ugrásszerủ és folyamatos fejlődésének a gazdasági tevékenység térbeli szerveződésére való hatása tudományos és politikai viták egész sorát váltotta ki.

Az 1960-as évektől kibontakozó vita során úgy vélték, hogy az új technológiák következtében a gazdasági te vékenység a centrumok irányából a perifériák irányába mozdul el, melynek következtében egy „globális falu” alakul ki (McLuhan 1964). Bairoch (1988) szerint a televízió fejlődése az egyik oka a városok „,zzétbomlásának”. Évtizedeken át ugyanis a rekreációs lehetőségek voltak azok, amelyek a városokba csábították a lakosságot, véleménye szerint azonban manapság a városi népesség és a vidéki társadalom legfontosabb kikapcsolódási eszköze egyaránt a televízió.

A kilencvenes évek elején az Internet kereskedelmi célú megnyitásával új lendületet kapott a vita. Úgy tủnt, hogy az Internet és az azzal járó kommunikációs forradalom felszabadítja a gazdaságot a földrajz béklyói alól. Mivel az IKT termékek könnyen áthidalják a fizikai távolságot és legyőzik a földrajzi akadályokat (Quah 1999), a digitális forradalom a "távolság halálát" jelenti majd (Cairncross 1997), hiszen az olyan ,súlytalan” javak, mint a szoftver, adatbázisok, elektronikus könyvtár, új média költségmentesen továbbíthatók. Az új technológiák lehetỏvé teszik azt is, hogy a munkaerő bárhol dolgozzon, így a digitális gazdaság elősegíti majd az elmaradott térségek gazdasági növekedését. Az új technológia hatása nemcsak az új gazdasági ágazatokban lesz érezhetö, hanem a hagyományos iparágak is profitálhatnak majd, hiszen minden eddiginél könnyebb lesz a világpiac elérése.

A Szilícium-völgy és más világszínvonalú IKT és high-tech iparágak koncentrációja, technológiai klaszterek kialakulása azonban éppen az ellenkezőjét mutatja. Ilyen esetekben ugyanis az IKT a korábban is előnyös helyzetben lévő régiók és nagyvárosok versenyképességének növekedéséhez járult hozzá. Úgy tünik tehát, 
hogy az információs technológia és a város szoros, egymást kölcsönösen támogató kapcsolatban van. Ennek Graham szerint három fö oka van:

1) Az IKT szektor a már meglevö, magas hozzáadott értékủ ipar és szolgáltatások mellé települ, meggyorsítva a város fejlödésének dinamikáját.

2) A törékeny globális világgazdaság, a valamennyi ágazatban növekvő komplexitás és innovációs kockázat azt eredményezte, hogy az IKT oda települt, ahol megfelelö az „innovációs miliő", hogy biztosíthassa a folyamatos versenyképességet.

3) Végül az IKT keresleti oldalát is a városok jelentik: mobil és vezetékes telefonhálózatot, számítógépes hálózatokat, internetszolgáltatásokat. Ennek fóbb okai: a nagyvárosok modernizációs kultúrája, a tőke koncentrációja, a relatíve magasabb elkölthetö jövedelem, a nemzetközi orientációjú és transznacionális társaságok magas koncentrációja (Graham 2000).

Ezek a tényezők a nagyvárosok helyzetét erősítették (Barsi-Csizmadia 2001). Ráadásul a nagyvárosokban koncentrálódnak a fontos döntéshozók, és minden korábbi várakozás ellenére a személyes kapcsolatok fontossága egyáltalán nem csökkent. A személyes találkozók során ugyanis a kommunikációs folyamat például a hangszínváltozásokkal, mimikával és taglejtésekkel is gazdagodik. Az is bizonyított, hogy a problémamegoldás kreativitása és hatékonysága nagymértékben megnő a személyes kontaktusok gyakoriságának növekedésével (Sweeney 1987). Ha a személyes kapcsolat már létrejött, akkor az a továbbiakban már fenntartható a technológia eszközeivel (telefon, fax, e-mail), de a személyes kontaktus továbbra is a kommunikáció elsődleges fontosságú területe marad (Grimes 2000). Meier-Dallach ezt úgy fogalmazta meg, hogy az IKT-nek a ,rutin kontaktusok” terén van nagy szerepe, de nem helyettesítheti a „döntéshozó kontaktusokat” (Meier-Dallach 1998).

Nem véletlen az internettartalom eloállítók nagy területi koncentrációja sem (Tuomi 2001). Ugyanis az ilyen cégeknek elengedhetetlen a megfelelö információhoz és tudáshoz való hozzáférés, méghozzá az olyan tudáshoz, amely nehezen fejezhetỏ ki digitális vagy szöveges formában. Ezt a problémát mutatja be Collins a tudományos információk átadásáról szóló tanulmányában (Collins 1975; 1987). Collins bemutatta, hogy gyakran szinte lehetetlen a tudományos tapasztalatot szimplán az eredmények leírásának elolvasásával megismételni. A leggyakrabban ehhez fizikai közelség és szituációs tudás szükséges.

Elméletileg tehát az IKT-nek mind centrifugális, mind centripetális hatásai is lehetnek. A térszerkezet végső formáját ezen eröknek a kölcsönhatása és eredője határozza meg.

\section{Az IKT-versenyképesség mérése, indikátorok}

Az elmúlt időszakban számos indikátor született az információs társadalom mérésére. Ezek az indikátorok mind statisztikai adatokat, mind felmérések, kérdőívek eredményeit tartalmazzák. Az információs társadalom statisztikai megfigyelése komoly kihívást jelent, hiszen az információs és kommunikációs technológiák 
rendkívül gyorsan fejlődnek, terjed alkalmazásuk, ami jelentősen behatárolja a statisztikai megfigyelés aktualitását.

Egy ország versenyképességének egyetlen indexbe való tömörítése nem könnyü feladat, nem véletlen tehát, hogy számos magán, kormányzati és akadémiai intézmény tett kísérletet a versenyképességi indikátor kidolgozására. Az elvégzett felmérések módszertana és célja igen különbözö, azonban alapvetően két fő cél köré rendezödtek:

- előtanulmány a megfelelő szakpolitika, értékelés és szabályozás kialakítására,

- az új technológiák elfogadottságának és használatának vizsgálata egy országban vagy közösségben.

A versenyképesség mérése körül kibontakozó vitát napjainkban két nemzetközi jelentés befolyásolja a legerőteljesebben. Az egyik az International Instutite for Management Development (IMD) által készített World Competitiveness Yearbook, a másik a World Economic Forum (WEF) által közzétett Global Competitiveness Report. ${ }^{1}$

Ezek a jelentések számos indikátor segítségével mérik az egyes országok versenyképességét. Az IMD évkönyve 314 kritérium alapján négy területet vizsgál: gazdasági teljesítmény, kormånyzati hatékonyság, vállalati hatékonyság és infrastruktúra, az egyes indikátorokat azonos súllyal szerepeltetve. Ezt a jelentést elsősorban a nemzetközi vállalkozások és befektetők használják az egyes országok gazdasági környezetének értékelésekor, telephely-választási és befektetési döntéseik során.

A WEF célja az egyes országok fenntartható növekedés elérésére való képességének vizsgálata. Ennek érdekében középtávon vizsgálják a nemzetgazdaságok szerkezetét, intézményeit és szakpolitikáit, melyeket az úgynevezett növekedés versenyképességi indexben foglalnak össze (growth competitiveness index). Az index kidolgozói különösen fontosnak tartották a technológiai fejlődés pontosabb mérését. Az úgynevezett „magországokban” a versenyképességi indexen belül 50\%-os súlyt képvisel a technológiai index, míg a többi országban 1/3-ost. A technológiai indexen belül mindkét országcsoporton belül 50\%-os súlyt képvisel az információs és kommunikációs alindex. Az IKT indexen belül 2/3-os súllyal szerepelnek az egy fóre vetített ,kemény” adatok (telefonvonalak, személyi számítógépek, internet-használat, internet-végpontok, mobiltelefon-használók száma), 1/3-os súllyal pedig a felmérésekből származó adatok (iskolai internet-hozzáférés, internetszolgáltatók közötti verseny, minőség, árak, az IKT szerepe a kormányzati politikában, az IKT-hez kapcsolódó jogi szabályozás) (McArthur-Sachs 2002).

A makroökonómiai versenyképesség mérésén kívül a WEF használ mikroökonómiai értelmú versenyképességi indexet is (current competitiveness index), mely elsôsorban a vállalatok müködését és stratégiáját, a vállalkozási kömyezet milyenségét vizsgálja.

A WEF jelentette meg a Globális információ-technológiai jelentést is, amelyben egy „,hálózati készültség indexet” dolgoztak ki, mely azt vizsgálja, hogy az egyes országok mennyire képesek kihasználni az információs és kommunikációs techno- 
lógiák adta lehetóségeket. $\mathrm{Az}$ index három fö alindexböl áll, melyek további alindexekre bomlanak:

- környezet

- piaci

- politikai/szabályozási

- infrastrukturális

- felkészülttség

- egyéni felkészültség

- üzleti szféra felkészültsége

- kormányzati szféra felkészültsége

- használat

- egyéni felkészültség

- üzleti szféra felkészültsége

- kormányzati szféra felkészültsége (Dutta-Jain 2002-2003)

A hálózati készültség indexet Finnország vezeti az Egyesült Államok és Szingapúr elött, Magyarország a harmincadik.

A hálózat használat szoros kapcsolatot mutat a jövedelemmel (egy före jutó GDP), tehát minél magasabb egy ország bruttó hazai terméke, annál nagyobb az információs és kommunikációs technológiát használók száma. Azonban az azonos GDP mutatóval rendelkezö országok között is nagy különbségek lehetnek, ami elsősorban egy másik, az alkalmassá tevö tényezök index alacsony értékének köszönhetö. Finnország és Franciaország például körülbeliul azonos nemzeti jövedelemmel rendelkezik, mégis a használati rangsorban Finnország az első, míg Franciaország a huszadik.

A jövedelem ugyanis csak egy bizonyos hálózathasználati szint eléréséig játszik jelentős szerepet, ezután már az alkalmassá tevő tényezök a dominánsak. Ha például a legalább 15000 dollár/fö GDP-vel (vásárlóerő paritáson számított) rendelkező országokat vizsgáljuk, akkor a hálózathasználat és a jövedelem között már nem találunk korrelációt. A 15000 dollár/fő alatti nemzeti jövedelem alatt mindkét faktor jelentős szerepet játszik (Kirkman-Osorio-Sachs 2002).

A WEF-hez hasonló módon hozott létre Rouvinen egy e-versenyképességi indexet (Rouvinen 2002). A felhasznált mutatók egy része ugyanis az internet elterjedtségéhez és használatához kapcsolódik, míg másik része az emberi és a szervezeti képességekhez:

- Az IKT elterjedtsége és használata

- mobiltelefon-előfizetök

- számítógép-használat

- feldolgozási képesség

- internet-hozzáférés

- az internethasználat gyakorisága

- az internethasználat mértéke

- elektronikus üzleti tevékenység

- tartalom-szolgáltatás 
Az információs és kommunikációs technológiák (IKT) hatása a versenyképességre.

Tér és Társadalom, 17. 2003. 3. 183-197. p.

TÉT XVII. évf. 2003 - 3

Versenyképesség

- IKT felkészültség

- IKT foglalkoztatottság

- IKT hozzáadott érték

$-\mathrm{K}+\mathrm{F}$ az IKT-ben

- IKT szabadalmak

- Emberi képességek

- befektetés a tudásba

- számítógéppel dolgozók

- IT oktatás és képzés minősége

- az IT képességek megjelenése a munkaeröpiacon

- Szervezeti képességek

- a politikai rendszer alkalmassága

- rugalmasság és alkalmazkodás

- a felhatalmazás delegálására való készség

- ösztönzési rendszerek mértéke

- vállalkozási aktivitás (Rouvinen 2002, 9).

Az Európai Unió statisztikai hivatala (EUROSTAT) szerint a következő témakörökben lehet leképezni az információs társadalmat:

- technikailag, ami azt jelenti, hogy a közlések középpontjában az információs technika alkalmazása áll,

- gazdaságilag, ami azt jelenti, hogy az információ, a kommunikáció, a tudáseloszlás tekintetében, az információtermelés minden területén figyelembe kell venni ezek hatását,

- a munkaerőpiacon megjelenő formákat: foglalkozási ágak, szakmák, munkakörök összetételének változásait,

- térbeli és idöbeli eloszlást, ami egyfelöl azt jelenti, hogy nyomon kell követni az információ globális terjedését, másfelöl annak időbeli alakulását,

- szociális-kulturális szférában, ezen belül az információ nyomon követését a mindennapi életben (Döry 2002).

Magyarországon a Központi Statisztikai Hivatal (KSH) 1998-ban kezdte meg az erősödő hazai információigényhez igazodó mérési feltételek kialakítását, majd 2000-ben ,az információs társadalom és a gazdaságstatisztika” fejlesztését.

Más oldalról közelítve a problémát azt mondhatjuk, hogy mindazokat a tevékenységeket, amelyek az információval, kommunikációval és az elektronikával összefüggésbe hozhatók, figyelembe kell venni, és az információs ágazatba kell sorolni. További szempontok szerint vizsgálható az egész folyamat keresleti és kínálati oldalról is. Kínálati oldalról, hogy mit állít elö az információs szektor, keresleti oldalról, hogy ezt hogyan használják fel a gazdasági szférában, illetve a háztartásokban.

A statisztika megkezdte hozzáigazítani módszereit az információs társadalomhoz, igaz többnyire csak a világ fejlettebb országaiban. Itt elsőrendủ szempont az összehasonlíthatóság. Az ENSZ és az OECD több ülésén is foglalkozott a számbavétel problémáival. A célok között szerepel az információs társadalom helyzetének, szerepének és fejlödésének mérésére szolgáló mutatórendszer kidolgozása. 
Az elmúlt években számos elméleti tanulmány született, melyek az IKT, az információs és kommunikációs technológiába való befektetés és a gazdasági vagy termelékenység növekedés közötti kapcsolatot vizsgálták (Dewan-Kraemer 2000; David 2001; Collecchia-Screyer 2002; Daveri 2002; Pohjola 2002). Ezek a munkák alapvetöen a termelési függvényböl, vagy a növekedési elméletekböl indultak ki.

A termelési függvény használata esetén egy Cobb-Douglas típusú függvényböl indulhatunk ki (Pohjola 2002):

$$
\mathrm{Y}=\mathrm{AC} \mathrm{C}^{\mathrm{ac}} \mathrm{K}^{\mathrm{ak}} \mathrm{H}^{\mathrm{ah}} \mathrm{L}^{\mathrm{al}}
$$

Ahol:

A: technikai haladás

$C$ : IKT-ba befektetett töke

$K$ : egyéb (nem IKT) töke

$H$ : humán tỏke

$L$ : munkaerö.

Ha az egyenlet természetes alapú logaritmusát vesszük, akkor az egyes megfigyelhető változók birtokában becsülhetjük meg $A, \alpha_{c}, \alpha_{k}, \alpha_{t}$ paramétereket. A legnagyobb probléma ebben az esetben a statisztikai adatok hiánya. A legtöbb esetben ugyanis kevés információ áll rendelkezésre az IKT tőkéröl, vagy a nemzeti jövedelemben való részesedéséről. A hivatalos adatok hiánya nehézkessé teszi a nemzetközi összehasonlítások végzését (Pohjola 2002).

A tőkeállomány nagyságának problémáját úgy kerülhetjük el, ha a növekedési elméleteket használjuk. Ekkor a neoklasszikus alapokon nyugvó kiterjesztett Solowmodellböl indulhatunk ki. Ekkor az egyszerü Solow modellt (Solow 1956) kiegészítjük a technikai haladással, amely a tudásban bekövetkezett olyan változás, amely lehetôvé teszi, hogy az adott munkaerő nagyobb outputot állítson elö. Ekkor a termelési függvény a következö:

$\mathrm{Y}=\mathrm{F}(\mathrm{K}, \mathrm{AL})=\mathrm{K}^{\alpha}(\mathrm{AL})^{1-\alpha}(2)$

Ha (2)-t elosztjuk (AL)-lel, akkor megkapjuk a termelékenységet: $y=k^{\alpha}(3)$, ahol $\mathrm{k}=\mathrm{K} /(\mathrm{AL})(4)$

$\mathrm{K}=\mathrm{sY}-\delta \mathrm{K}(5)$, ahol

$s:$ megtakarítási hányad

$\delta$ : a töke értékcsökkenése.

A termelékenység időbeli változásának alakulását ezért a következőképpen írhatjuk fel:

$\Delta \mathrm{k}_{\mathrm{l}}=\mathrm{sy}_{\mathrm{t}}-(\delta+\mathrm{n}+\mathrm{a}) \mathrm{k}_{\mathrm{t}}(6)$, ahol

a: a technológia konstans növekedési üteme,

$n$ : a munkaerỏ növekedési üteme.

Egyenletes növekedési ütem esetén $\Delta \mathrm{k}_{1}=0$. 
Állandó növekedés esetén tehát:

$\mathrm{k}^{*}=[\mathrm{s} /(\delta+\mathrm{n}+\mathrm{a})]^{1 /(1-a)}(7)$.

Így állandó növekedési ütem esetén a termelékenység a következöképpen alakul (3)-ba behelyettesítve:

$\mathrm{y}^{*}=[\mathrm{s} /(\delta+\mathrm{n}+\mathrm{a})]^{\alpha /(1-\alpha)}$

Mindebböl az következik, hogy a termelékenység pozitív kapcsolatban van bármely tökébe való befektetéssel (a tökéket különbonthatjuk (1)-hez hasonlóan), és negatív kapcsolatban a munkaerő növekedési ütemével, valamint a tỏke értékcsökkenésével.

A kiterjesztett Solow-modellböl tehát az következik, hogy az IKT-ba történő befektetésnek a termelékenység és az output növekedéséhez kellene vezetnie.

A modell empirikus vizsgálata azonban azt mutatta, hogy az információs és kommunikációs technológiába történö befektetés nem járul hozzá szignifikánsan a termelékenység növekedéséhez (Oliner-Sichel 1994; Jorgenson-Stiroh 1995; Collechia-Schreyer 2002; Daveri 2002). Vagyis az IKT esetén érvényesül az úgynevezett Solow-paradoxon. Solow mindezt úgy fogalmazta meg, hogy ,manapság mindenütt a számítógépek koráról van szó, kivéve a termelékenységi statisztikákban” (Solow 1987, 36). Az 1. ábrán az Egyesült Államok teljes tényezỏ termelékenységét (TFP) és a kutatók és mérnökök népességhez viszonyított arányát vizsgálva például megállapíthatjuk, hogy míg a tudományos területen dolgozók és a mérnökök száma folyamatosan emelkedett, a termelékenység nagymértékben ingadozott.

\section{1. ÁBRA}

A kutatók/mérnökök száma és a termelékenység az Egyesült Államokban

(Number of scientist/engineers and productivity in the United States)
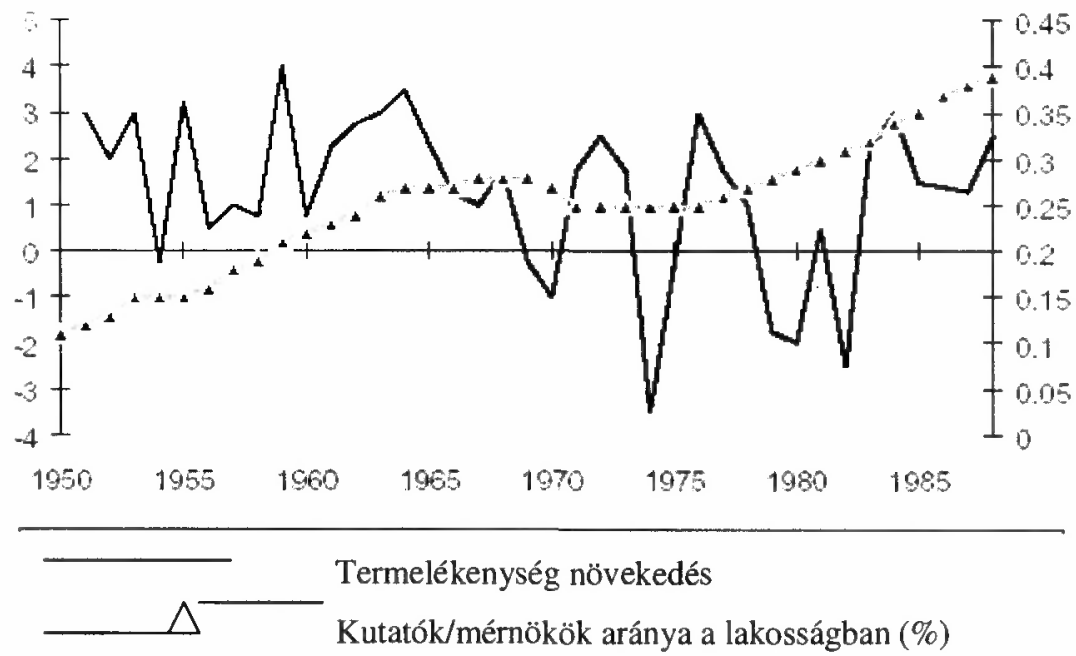

Forrás: Quah 1999. 
Még inkább meglelö, hogy néhány empirikus vizsgálat negatív összefüggést mutatott (Loveman 1988; Berndt-Morrison 1995).

A Solow-paradoxon megjelenését egyrészt a neoklasszikus modell alkalmazása magyarázza, még akkor is, ha eltekintünk a Cobb-Douglas termelési függvény alkalmazása, az állandó értékcsökkenés minden tőketípus esetén, valamint az egyenletes növekedés okozta problémáktól ${ }^{3}$.

A neoklasszikus modell ugyanis nem képes megragadni az információs vagy tudás-társadalom alapvető jellemzőit. A modell mögött ugyanis az az alapvetö feltételezés nyugszik, hogy hosszú távon a tudás (technológia) a növekedés alapvető forrása. Tehát a növekedés a humán tỏke (képességek, a munkaerő képzése), mint direkt input befektetése a tudás elöállításába és a gépek üzemeltetésébe. Ez igaz volt az ipari forradalom idején, amikor is egy tudás (találmány, szabadalom) feletti monopólium egyrészt a szabadalomból eredö jövedelem, másrészt a jobb eszközök és gépek alkalmazásának következtében pozitív járadékot hozott a tudás tulajdonosának, amit újabb tudás finanszírozásába és előállításába fektethetett be (Quah 1999).

Az információs társadalomban azonban nem egyszerủen arról van szó, hogy jobb technológia van a birtokunkban, hanem arról, hogy a tudás közvetlenül jut el a fogyasztókhoz a szoftvereken vagy a genetikailag módosított élelmiszereken keresztül.

Szintén problémát jelent, hogy maguk a termékek sokszor olyan mértékben koncentrálnak tudást, hogy maguk is tudásként viselkednek, vagyis például végtelenül hozzáférhetök, végtelen a terjedelmük. (Ha egy fogyasztó letölt egy szoftvert Budapesten, és azt használja, attól még az ugyanabban az időben, Londonban a szoftvert installáló vásárló fogyasztási élvezete nem csökken.) A meglévő termékek és szolgáltatások esetében pedig olyan fokú minőségi ugrás következett be, amit szintén nem tud megragadni a hivatalos statisztikai mérés.

Szintén az új típusú termékek következménye az, hogy a termelékenységi és versenyképességi hatások nagymértékben függnek az intézményi szervezeti struktúráktól is.

Más magyarázat szerint (Triplett 1999) a számítógépek gazdasági hatását egyáltalán nem a termelékenység területén kell keresni. A befektetett töke, és maga a számítógépipar növekedése azzal magyarázható, hogy a számítógépek ára óriási mértékben csökkent és ez nagymértékủ helyettesítéshez vezetett.

Az utóbbi évek nagy IKT befektetései ráadásul általában a számítógépek és szoftverek használatának egyszerüsítésére irányultak. Ezt azonban gazdasági statisztikákban nagyon nehéz mérni. Hasonló problémák adódnak, amikor az IKT vállalati szerkezetre, szervezetre, hatékonyabb struktúrára gyakorolt hatását próbálnánk beilleszteni a modellbe.

Mások arra figyelmeztetnek (Oliner-Sichel 2000; Pohjola 2002), hogy kevés idő telt el az IKT befektetések valódi növekedése óta, és az összes befektetésnek még mindig csak kis hányadát jelentik. Ezért a valódi termelékenységi hatások modellezhető bemutatására még várni kell, és a korábban végzett empirikus vizsgálatok ezért nem mutathatták ki a pozitív összefüggést. Mivel a termelékenység-növelö hatás eléréséhez idöre van szüksége (David 2001), ezért az IKT termelékenységre gyakorolt hatásának (kezdeti) negatív összefüggései is magyarázhatók, hiszen az 
IKT elterjedésének költsége van (tanulási költségek), ami időben - a használók számának növekedésével - csökken. David (1990) analógiát von az elektromosság és a számítógépek elterjedése között, sajátos, hálózati jellemzőjük miatt. Bemutatja, hogy az első üzleti célokat szolgáló erőmủ beindítása után hosszú évtizedeknek kellett eltelni, amíg az elektromosság elterjedt a feldolgozóiparban.

Ez a megközelítés a pozitiv externáliákra is felhívja a figyelmet. Ugyanis, ahogy az IKT használatának képessége (tudás) egyre inkább elterjed, az felgyorsítja magának a technológiának a diffúzioját is. Az, hogy egyre több IKT-hez hozzáféró felhasználó pedig az összes alkalmazó használatból származó hasznosságát növeli, ismételten hozzájárul a diffúzió felgyorsulásához

\section{Konklúzió}

A versenyképesség és annak mérése az információs társadalomban sok nehézséget jelent. Az új technikának a termelékenységre és ezen keresztül a versenyképességre gyakorolt hatása önmagában nem túl jelentős. Az új gazdaság nem csodaszer, nem old meg minden gazdasági fejlődésbeli problémát. A gazdasági tevékenység globalizációja és az információs forradalom azonban az elkövetkezö évtizedek legfontosabb világgazdasági jelensége marad.

Az információs és kommunikációs technológiából származó előnyök hosszú távon jóval túlszárnyalják majd az IKT elöállitásából, termeléséből származó előnyöket.

Az Egyesült Államok és néhány európai ország sikere azt bizonyítják, hogy az új gazdaságban a versenyelönyök nem az alacsony költségü termelésben rejlenek, hanem a technológiai, szervezeti és vezetési innovációk adoptálásában, melyek növelik a versenyképességet.

\section{Jegyzetek}

${ }^{1}$ Az említett két jelentés mellett a Világbank World Development Report-ja foglalkozik a hosszú távon sikeres fejlesztési politika elérésének kérdéseivel, valamint az EBRD készíti el az ún. Transition Report-ot, amely speciálisan a volt szocialista országokkal foglalkozik.

${ }^{2}$ A WEF a vizsgált 75 országot a technológiai fejlettség alapján magállamokra és nem mag államokra osztotta. Magállamok azok az országok, amelyekben az egy millió före jutó bejegyzett szabadalmak száma meghaladja a 15-öt.

${ }^{3}$ Hasonlóan nem képesek megragadni az információs társadalom természetét a neoklasszikus modell utáni növekedés elméletek sem.

\section{Irodalom}

Bairoch, P. (1988) Cities and Economic Development. University Press, Chicago.

Barsi B.-Csizmadia Z. (2001) Egy nagyváros helyzete az információs társadalomban. - Tér és Társadalom. 2, 147-172. o.

Barsi B. (2002) Egy kisváros helyzete az információs társadalomban. - Tér és Társadalom. 3. 85-102. o.

Berndt, E.R.-Morrison, C.J. (1995) High-tech capital formation and economic performance in U.S. manufacturing industries: An exploratory analysis. - Journal of Econometrics. 69. 243-268. o.

Cairncross, F. (1997) The Death of Distance. Harvard Business School Press, Cambridge. 
Carayannis, E.-Sagi, J. (2001) „New” vs. „old” economy: insights on competitiveness in the global IT industry. - Technovation. 21. 501-514. o.

Castells, M. (1996) The Information Age: Economy, society and Culture: Volume I: The Rise of the Network Society. Blackwell Publishers, Cambridge.

Castells, M. (1997) The Information Age: Economy, society and Culture: Volume II: The Power of Identity. Blackwell Publishers, Cambridge.

Clark, J.-Guy, K. (1997) Innovation and Competitiveness. Technopolis, Brighton.

Collecchia, A.-Schreyer, P. (2002) ICT Investment and Economic Growth in the 1990s: Is the United States a Unique Case? A Comperative Study of Nine OECD Countries. - Review of Economic Dynamics. April. 408-442. o.

Collins, H.M. (1975) The seven sexes: a study in the sociology of a phenomenon, or the replication of experiments in physics. - Sociology. 9. 205-224. o.

Collins, H.M. (1987) Expert systems and the science of knowledge. - Bijker, W. e.-Hughes, T.P.-Pinch, T. (eds.) The Social Construction of Technologocal Systems: New Dimensions in the Sociology and History of Technology. MIT Press, Cambridge. 329-438. o.

Daveri, F. (2002) The New Economy in Europe 1992-2001. WIDER Discussion Papers 70.

David, P.A. (1990) The dynamo and the computer: an historical perpective on the modern productivity paradox. - American Economic Review. May. 355-361. o.

David, P.A. (2001) Productivity Growth Prospects in the New Economy in Historical Perspective. European Investment Bank Papers. 6. 41-61. o.

Dewan, S.-Kraemer, K.L. (2000) Information Technology and Productivity: Evidence from CountryLevel Data. - Management Science. 46. 548-562. o.

Döry T. (2002) Az információs társadalom fejlödésének és statisztikai megfigyelésének nemzetközi trendjei, valamint a hazai tapasztalatok. - Döry T.-Grosz A. (szerk.) Az információhoz való hozzájutás társadalmi és földrajzi különbségei Magyarország városhálózatában. 137. sz. Közlemény, MTA RKK Nyugat-magyarországi Tudományos Intézet, Györ. 5-50. o.

Dutta, S.-Jain, A. (2002-2003) The Networked Readiness of Nations. - Dutta, S.-Lanvin, B.-Paua, F. (eds.) Global Information Technology Report 2002-2003. Oxford University Press, Oxford-New York. 2-26. o.

Entrepreneurship in the Netherlands. New economy: new entrepreneurs! (2001) EIM Business and Policy Research, Den Haag.

Graham, S. (2000) Bridging Urban Digital Divides? Urban polarization and Information and Communications Technologies (ICT): Current Trends and Policy Prospects. Backgorund paper for the United Nations Centre for Human Settlements (UNCHS), New York.

Grimes, S. (2000) Rural areas in the information society: diminishing distance or increasing learning capacity? - Journal of Rural Studies. 16. 13-21. o.

Jorgenson, D.W.-Stiroh, K. (1995) Computers and growth. - Economics of Innovation and New Technology. 3-4. 295-316. o.

Kirkman, G.S.-Osoria, C.A.-Sachs, J.D. (2002) The Networked Readiness Index: Measuring the Preparedness of Nations for the Networked World. - Kirkman, G.S.-Cornelius, P.K.-Sachs, J.D.Schwab, K. (eds.) Global Information Technology Report 200l-2002. World Economic Forum, Genf. 10-29. o.

Krugman, P. (1994) Competitiveness: A Dangerous Obsession. - Foreign Affairs. March/April. 28-44. o.

Leadbeater, C.-Ussher, K. (1999) Europe's new economy. CER Bulletin 9. London.

Lengyel I. (2000) A regionális versenyképességröl. - Közgazdasági Szemle. december. 962-987. o.

Loveman, G.W. (1988) An Assessment of Productivity Impact of Information Technologies - Allen, T.J. -Morton, M.S.S. (eds.) Information Technology and the Corporation of the 1990s. Research Studies, MIT Press, Cambridge. 84-110. o.

Marshall A. (1890) Principles of Economics, Macmillan, London.

McArthur, J.W.-Sachs, J.D. (2002) The Growth Competitiveness Index: Measuring Technological Advancement and the Stages of Development. - Sachs, J.D.-Porter, M.E.-Schwab, K. (eds.) Global Competitiveness Report 2001-2002. World Economic Forum, Genf. 28-51. o.

McLuhan, M. (1964) Understanding Media: The Extension of Man. McGraw-Hill, New York.

Meier-Dallach. H.P. (1998) The end of regions. - Hetland, P.-Meier-Dallach, H.P. (eds.) Domesticating the World Wide Webs of Information and Communication Technology. European Commission, Luxemburg. 283-304. o.

Nagy G. (2002) Területi különbségek az információs korszak küszöbén. (Mit mérünk, és hogyan?) Területi statisztika. 1. 3-25. o.

Nanclares, N.H. (2001) The so called new economy and the ICT: concept and measurement. - Brazilian Electorinic Journal of Economics. 1. http://www.beje.decon.ufpe.br/v4n1/nanclares.htm 
Oliner, S.D.-Sichel, D.E. (1994) Computers output growth revisted: How big is the puzzle? - Brookings Papers on Economic Activity. 2. 273-317. o.

Oliner, S.D.-Sichel, D.E. (2000) The Resurgence og Growth in the Late 1990s: Is Information Technology the Story? - Journal of Economic Perspectives. 14. 3-22. o.

Palánkai T. (2002) Összefoglaló az integrációérettség mérésének kutatásáról. - Kutatások az integrációérettség témaköréböl. Európai Tükör Mühelytanulmányok. 86. 9-117. o.

Pohjola, M. (2002) New Economy in Growth and Development. WIDER Discussion Papers 67.

Porter, M.E. (1990) The Competitive Advantage of Nations. The Free Press, New York.

Porter, M.E. (2002) Enhancing Microeconomic Foundations of Prosperity: The Current Competitiveness Index. - Sachs, J.D.-Porter, M.E.-Schwab, K. (eds.) Global Competitiveness Report 2001-2002. World Economic Forum, Genf. 2-26. o.

Quah, D. (1999) Growth and Increasingly Weightless Economies. - The Ecoonomics of the Knowledge Driven Economy. DTI, London. 22-30. o.

Rechnitzer J. (2003) Az információs társadalom térformáló szerepe. - eVilág, február. 16-21. o.

Rechnitzer J.-Grosz A.-Csizmadia Z. (2003) A magyar városhálózat tagozódása az infokommunikációs infrastruktúru alapján az ezredfordulón. - Tér és Társadalom. 3. 145-163. o.

Rouvinen, P. (2002) Competitiveness in the New Economy. ETLA Discussion Papers No. 786. Helsinki.

Solow, R. (1956) A Contribution to the Theory of Economic Growth. - Quarterly Journal of Economics. február. 65-94. 0 .

Solow, R. (1987) We'd better watch out. - New York Times. Július 12. 36. o.

Sweeney, G.P. (1987) Innovation, Entrepreneurs and Regional Development. Frances Pinter, London.

Triplett, J.E. (1999) The Solow productivity paradox: what do computers do to productivity? - Canadian Journal of Economics. 2. 309-334. o.

Tuomi, I. (2001) From Periphery to Center: Emerging Research Topics on Knowledge Society. TEKES, Helsinki.

Veress J. (2001) Új gazdaság - Internet gazdaság. - Európa 2002. 1. 1-22. o. 